same pathway. Slife et al. [J. Biol. Chem. (1989) 264, 1037110377] has also noted sphingomyelinase treatment of liver plasma membrane to generate sphingosine, possibly derived from ceramide of sphingomyelin, though this did not occur with endoglycoceramidase. However, cleavage of gangliosides was distinct. Both papers clearly indicate ceramides derived from glycosphingolipids to differ in metabolic fate from that of sphingomyelin. This appears at variance with the work of Tettamanti and his associates who found that following administration of gangliosides labelled at the sphingosine portion to cultured cells, some of them were used again as sphingomyelin and also as other forms of glycosphingolipids [for example, $J$. Neurochem. (1989) 53, 1567-1574].

Reported by Tatsuya YAMAGATA Laboratory of Glycoconjugate Research Mitsubishi Kasei Institute of Life Sciences Tokyo 194, Japan
LCで確認されるが、つまりセラミドが生じていると思われる にも拘らず、スフィンコシンの生成は認められないことを報告 している。一方、肝細胞形質膜をスフィンゴミエリナーゼで処 理するとセラミド経由でスフィンゴシンが生成しているのであ る。このふたつの論文は、榶脂質由来のセラミドとスフィンゴ ミエリン由来のセラミドとは、その代謝運命が明らかに異なる ことを意味している。両者の化学構造に差があるのであろう か。Tettamantiらの実験によると、スフィンゴシン部分を標識し たガングリオシドを培美細胞に与えると、細胞に取り込まれた ガングリオシドは速やかに代謝を受けて、他の種類の糖脂質に なる以外に、スフィンゴミエリンにもなるという [J. Neurochem. (1989) 53，1567-1574]。これは、合成に関して は糖脂質もスフィンコミエリンもセラミドを共有しているわけ であり、今回のように分解において運命の差が示唆されたのは 大変面白い。細胞表層上で糖脂質が直接分解を受けて、セラミ ドになるということは通常はないわけで、従って、細胞にはそ の用意がないためであろうか。

三菱化成生命科学研究所 複合糖質研究室

山形 達也

\title{
Defined Geometry of Binding between Triantennary Glycopeptide and the Asialoglycoprotein Receptor of Rat Hepatocytes
}

\author{
ラット肝ガラクトースレセプターとトリアンテナ糖ペプチド間の結合の幾何学的解析
}

\author{
K. G. Rice, O. A. Weisz, T. Barthel, R. T. Lee and Y. C. Lee \\ J. Biol. Chem. (1990) 265,18429-18434
}

The asialoglycoprotein receptor of rat hepatocytes comprises of a major subunit of RHL $1(41.5 \mathrm{kDa})$ and two minor subunits of RHL $2(49 \mathrm{kDa})$ and RHL $3(54 \mathrm{kDa})$ [Proc. Natl. Acad. Sci. USA (1981) 78, 3348-3352]. Lee and co-workers have reported the cluster effect (an increase in the binding strength beyond that expected from the increase in sugar concentration) in certain receptor systems. For instance, galactoseterminated diantennary and triantennary oligosaccharides manifest about $10^{3}$ - to $10^{6}$ - fold higher affinity toward the asialoglycoprotein receptor on the hepatocyte surface than a monoantennary oligosaccharide, although the actual galactose concentration is increased by only 2 - and 3-fold, respectively [J. Biol. Chem. (1983) 258, 199-202]. The high affinity of triantennary oligosaccharide to the receptor can be explained if the spatial rearrangement of the three galactoses of the ligand fits perfectly to the binding sites of the receptor molecule.

In the present study, three derivatives of a triantennary glycopeptide, each containing a single uniquely located 6amino-galactose residue at either position 6, 6 and 8, were modified at the 6-amino group by attachment of a photolyzable reagent to investigate the geometry of ligand-receptor interaction. Each probe labeled either the major (RHL 1) or minor
ラット肝ガラクトースレセプター（アシアロ榶タンパクレ セプター）分子は三種のサプュニット、RHL1（分子量41.5k タ ルトン)，2（49k タルトン），3（54k タルトン）からなり、 このうちRHL 1が主要な構成成分である[Proc. Natl. Acad. Sci. USA(1981) 78, 3348-3352]。Leeのグループは、このレセプター 系で、天然 $\mathrm{N}$ ーグリコシド型榶鎖の化合物の糖鎖の枝（アンテ ナ）か、1本（モノ）から2本（ジ）を経て3本（トリ）に増 えるに従って、そのレセプターへの䊅合力が約千倍から百万倍 まで增加するという“クラスター効果”を報告してきた[J. Biol. Chem. (1983) 258, 199-202]。このように、トリアンテナ型桾鎖を 有する化合物がガラクトースレセプターに強い親和性を示すの は、その末端に存在する 3 つのガラクトース残基が形成する三 次元空間的構造が、レセブター分子に存在するガラクトース䊅 合部位の配置に適合するためと理解される。

この論文では、この点をさらに詳細に検討するために、 フェツインより調製したトリアンテナ榶べブチドの 3 つのガラ

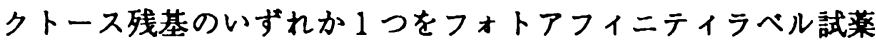
で修飾した 3 種の誘導体を作成している。この誘導体をプロー ブとすることにより、ラット肝細胞をそのまま用いた場合、レ セブターを構成しているPH L 1 あるいはPHL $2 / 3$ のい ずれかが選択的に標識された。ガラクトース残基 6 あるいは 6’を修飾したブローブはR H L 1 のみを選択的に標識したの に対し、ガラクトース残基 8 を修飾したブローブは、マイナー 
(RHL 2/3) subunits specifically. A probe modified at galactose residue 6 or 6 ' only labeled RHL 1 , whereas a probe modified at galactose 8 specifically labeled RHL $2 / 3$. However, after solubilization, no such fine specificity could be observed, and all the probes resulted in labeling only the major subunit (RHL 1). Their findings have revealed the astonishingly precise geometry of binding between the three galactose residues of triantennary glycopeptide and the three subunits of the asialoglycoprotein receptor of rat hepatocytes. Furthermore, their data support that the receptor is a hetero-oligomer of RHL 1 and RHL 2/3 subunits.

Thus, Lee's group continues to utilize well-characterized compounds of natural, synthetic or semisynthetic origin for elucidation of binding modes of carbohydrate receptor. Further application will throw a new light upon this research field.
なサブユニットであるR H L 2/3 を選択的に標識した。しか し、可溶化して単部したレセブターを用いた場合には、もはや このマイナーサブユニット（R H L 2/3）はガラクトース残 基 8 を修飾したブローブでも標識されず、また、いずれのプロ ーブもRH L 1 のみを標識した。以上の䊅果はトリアンテナ榶 ペブチドに存在する 3 つのガラトース残基とラット肝細胞表面

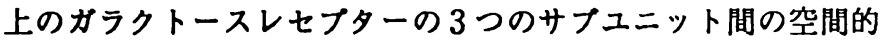
位置関係を明らかにするものである。さらに、ラット肝細胞表 面のガラクトースレセブターは、RHL 1 とRHL 2/3 サブユニッ トから棈成されたへテロオリコママーであることを支持するもの である。

このように、Leeのグルーブは、唃鎖を認識するレセプタ 一の䊅合様式を調へろるたに天然由来、合成あるいは半合成に より、その構造が明確な化合物を利用する点にあり、さらなる 応用が期待される。

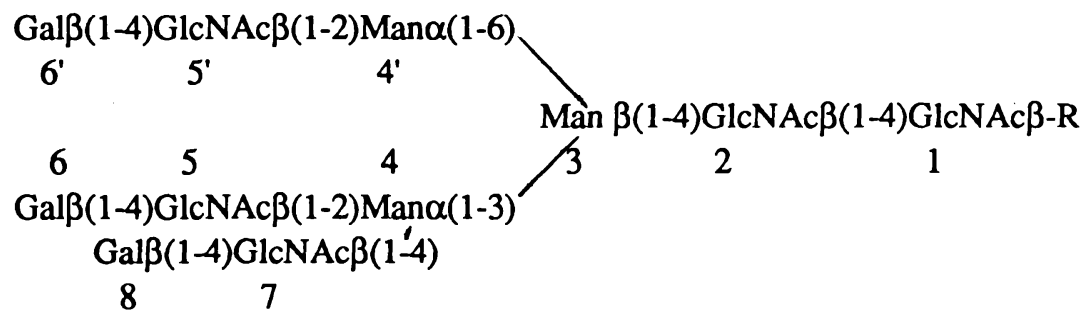

Reported by Hiroshi TOMODA

北里研究所

The Kitasato Institute, Tokyo 108, Japan

供田 洋

\title{
Tumor Cell Surface $\beta 1$-4-Linked Galactose Binding to Lectin(s) on Microvascular Endothelial Cells and Contribution to Organ Colonization
}

\author{
腫瘍形成に寄与する \\ Isabelle Comil, Robert S. Kerbel, and James W. Dennis \\ J. Cell Biol. (1990) 111, 773-781
}

腫瘍細胞表層の $\beta$ 1-4結合ガラクトースは毛細血管内皮細胞のレクチンに結合し、

Cell surface carbohydrates acting as ligands for tissue specific mammalian lectins may possibly be involved in cellcell interactions during lymphocyte homing and tumor cell metastasis. For instance, mannose-6-phosphate inhibits lymphocyte homing to lymph nodes and attachment to high endothelium of postcapillary venules. Gal-BSA and asialofetuin inhibits homing of lymphocytes to bone marrow, and Gal-binding lectins have been identified on bone marrow endothelial cells, their presence possibly important for organ retention and colonization by blood bone cells. The intravenous infusion of galacto- or arabinogalactan inhibits organ colonization by
細胞表層の糖鎖は組織特異的に発現されるレクチンのリガ ンドとして働き、リンバ球のホーミングや腫瘍の転移の際の細 胞間相互作用を担っていることが明らかにされつつある。例え ばマンノースー6ーリン酸はリンバ球がリンバ節にホーミング し、高内皮細胞へ接着するのを阻害することが示されている。 Gal-BSAとアシアロフェツインはリンバ球が骨㕼にホーミング するのを阻害する。骨噵内皮細胞からは逆にGal-結合レクチン が単離され[Kataoka and Tavassoli (1985) Blood 65, 1163-1171]、 